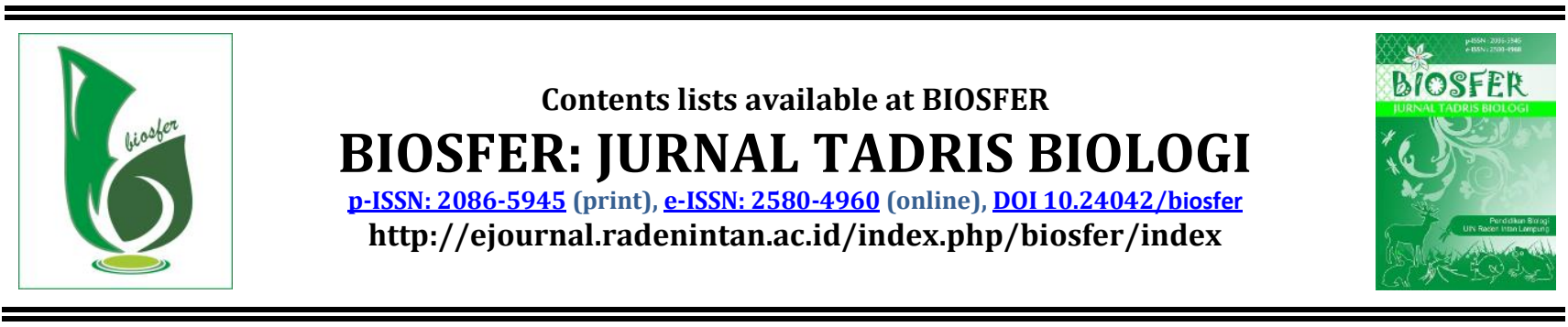

\title{
The Influence of Resource-based Learning Model based on Flashcard toward Students' Problem-Solving Abilities
}

\author{
Debbi Angelica ${ }^{*}$, Aulia Novitasari ${ }^{2}$ \\ ${ }^{1,2}$ Raden Intan State Islamic University of Lampung, Indonesia
}

\begin{abstract}
ARTICLE INFO
\section{Article History}

Received: April 14th 2020

Accepted: May $16^{\text {th }}, 2020$

Published: June $30^{\text {th }}, 2020$

Keywords:

Resource-based learning

Model;

Flashcard Media;

Problem-solving.

*Correspondence Address:

Debbiangelica96@gmail.com

ABSTRACT

Abstract: The purpose of this research was to determine the influence of the Resource-based learning model (RBL) based on flashcards on students' problem-solving abilities and motivation. The design of this research quasi-experimental with a posttest only control group design. The data analysis techniques employed in this research were the normality test using the Lilifors test and the MANOVA test to determine the hypothesis. Based on the analysis, the MANOVA test to determine the average score difference of students' problem-solving abilities in the experimental class and the control class obtained a sig value of 0.00 so that sig. 2 (tailed) $\leq 0.05$ which indicated that $\mathrm{H}_{0}$ was rejected and $\mathrm{H}_{\mathrm{i}}$ was accepted. Therefore, it can be concluded that the Resource-based learning model (RBL) based on flashcards influenced the students' problem-solving abilities and learning motivation.
\end{abstract}

\section{Pengaruh Model Resource-based learning Berbasis Media Flash Card Terhadap Kemampuan Pemecahan Masalah}

\begin{abstract}
Abstrak: Tujuan dari penelitian ini yaitu untuk mengetahui apakah ada pengaruh dan untuk melihat besarnya pengaruh model pembelajaran Resource-based learning (RBL) berbasis media flash card terhadap kemampuan pemecahan masalah dan motivasi belajar. Penelitian ini merupakan jenis penelitian Quasy Experimental Design, dengan desain penelitian berupa Control Group Design. Teknik analisis data penelitian ini dengan menggunakan uji normalitas dengan uji Lilifors dan uji Manova untuk menentukan hipotesisnya.Berdasarkan data hasil penelitian diketahui bahwa hasil Uji Manova untuk perbedaan rata-rata nilai kemampuan pemecahan masalah kelas eksperimen dan kelas kontrol diperoleh nilai sig 0,00 sehingga sig. 2(tailed) $\leq 0,05$. Sesuai kriteria Uji Manova bahwa HO ditolak dan Hi diterima, maka dapat disimpulkan bahwa hipotesis ada perbedaan antara model Resource-based learning (RBL) berbasis media flash card terhadap kemampuan pemecahan masalah dan motivasi belajar.
\end{abstract}




\section{INTRODUCTION}

A more advanced national civilization is needed to build potential (Sinambela, L. P, 2017) so that every human being could have a better life, able to face challenges, and able to take advantage of existing opportunities (Hadi, A., 2013; Marwiyah, S., 2012). In this 4.0 era, education is developed continuously so that it can improve problemsolving abilities to find solutions to a problem (Agustiana dkk., 2019; HASANAH, U. N., Thahir, A., Komaruddin, K., \& Rahmahwaty, R., 2019; Raharja, H. Y, 2019).

To be more active and independent, it is necessary to develop learning motivation through social activities to improve problemsolving abilities in everyday life (Huda, M., 2015; Insyasiska, D., Zubaidah, S., \& Susilo, H, 2017). Problem-solving abilities are very useful to build a logical, targeted, and systematic view of making decisions from various points of view (Fanani, M. Z., 2018). In the learning process, students must also possess motivation, encouragement, and enthusiasm to take action in the problem-solving process (Balqis, P., Ibrahim, N. U., \& Ibrahim, S., 2014; Daud, F., 2012).

Motivation is characterized by the emergence of curiosity about something (Emda, A., 2018; Makmur, A., \& Aspia, A., 2015; Susanti, M. D., 2015), In this case, motivation is related to psychology and emotions that can determine human behavior (Cleopatra, M., 2015; Daud, F., 2012; Suardana, A. A. P. C. P., \& Simarmata, N., 2013). Thus, motivation is needed to encourage humans to determine the direction of the actions to be carried out (Emda, A., 2018; Suprihatin, S, 2015). Motivation to learn will rise if the learning activities are appropriate with the limit of abilities (Munib, A., 207M). Thus, motivation or encouragement can improve problem-solving abilities in everyday life (Amri, M. S., \& Abadi, A. M., 2013; Setiawan, I. G. A. N., \& Nyoman, G. A., 2018).

The most important factor that affects problem-solving abilities is learning motivation (Nurfitriyanti, M, 2016; Suprihatin, S, 2015). Changes or innovations in the learning process need to be made. One of the learning models that invite students to be active in the learning process is the Resource-based learning model (RBL) based on flashcards. This model can help the students to explore their knowledge so that they can be more active. The flashcard can be used because its contents are very simple and fun (Nurseto,T, 2011; Rifqiawan, R. A, 2017).

\section{METHOD}

This research was conducted at SMA YP Unila Bandar Lampung. The research method applied was quasiexperimental with a posttest only control group design. The research was conducted by giving different treatments to two classes, namely the experimental class using the Resource-based learning model based on a flashcard and the control class using the direct learning model through lecturing and discussion. The independent variable in this study was the Resource-based learning model based on flashcards while the dependent variable was the students' problem-solving ability and learning motivation.

The cluster random sampling, technique, which is the technique of selecting a sample based on small groups or classes, was employed to determine the sample (Puspita dkk., 
2020). Based on the results of the sampling process, class MIPA 1 which consisted of 30 students was chosen as the experimental class and class MIPA 3 which consisted of 30 students was chosen as the control class. The data collecting techniques employed in this research were tests and questionnaires that had been validated by lecturers who were experts in their fields.

The instruments were tested using the validity test, reliability test, discrimination index, and the level of difficulty test. Before the hypothesis test was carried out, the prerequisite tests in the form of normality and homogeneity tests had been carried out using the MANOVA assisted by SPSS 17.

\section{RESULTS AND DISCUSSION}

The instruments which consisted of 16 questions had been declared as valid and reliable. The normality test using the Liliefors test discovered that the sample was normally distributed. It was proven by the results of the calculation where the value of Lobserved <Lcritical. The normality value of the experimental class was 0.098 while the control class was 0.133 with the Lcritical value of 0.161 . So, it can be concluded that $\mathrm{H}_{0}$ for both classes was accepted.

The homogeneity test using the Barlett test, commonly called the Box' $M$ test, had been done to see the distribution of two homogeneous data. The calculation was performed using SPSS.17. The sig value of was Box' $M=0.060>0.005$, thus Ho was accepted. It can be concluded that the two data group variances were homogeneous.

The hypothesis for the dependent variable on problem-solving abilities and student motivation can be seen in the table above. Based on the first hypothesis (Hi: $\mu 1 \neq \mu 3$ ), there was a difference in learning motivation between students who were taught using a flashcard-based RBL model and students who were taught using direct instruction. Based on the second hypothesis (Hi: $\mu 1 \neq \mu 3$ ), there was a difference in problem-solving ability between students who were taught using a flashcard-based RBL model and students who were taught using direct instruction. The data can be seen in the following table.

Tabel 1. Between-Subjects Effects Tests

\begin{tabular}{lllllll}
\hline \multirow{2}{*}{ Source } & $\begin{array}{l}\text { Dependent } \\
\text { Variable }\end{array}$ & $\begin{array}{l}\text { Type III Sum } \\
\text { of Squares }\end{array}$ & df & Mean Square & F & Sig. \\
\hline $\begin{array}{l}\text { Corrected } \\
\text { Model }\end{array}$ & $\begin{array}{l}\text { Problem- } \\
\text { solving Ability }\end{array}$ & $3526.667^{\mathrm{a}}$ & 1 & 3526.667 & 36.405 & .000 \\
& $\begin{array}{l}\text { Motivation } \\
\text { Intercept }\end{array}$ & $46.817^{\mathrm{b}}$ & 1 & 46.817 & 1.110 & .000 \\
& $\begin{array}{l}\text { Problem- } \\
\text { solving Ability }\end{array}$ & 358826.667 & 1 & 358826.667 & 3704.072 & .000 \\
& Motivation & 397394.817 & 1 & 397394.817 & 9425.539 & .000 \\
Class & $\begin{array}{l}\text { Problem- } \\
\text { solving Ability }\end{array}$ & 3526.667 & 1 & 3526.667 & 36.405 & .000 \\
& $\begin{array}{l}\text { Motivation } \\
\text { Error }\end{array}$ & 46.817 & 1 & 46.817 & 1.110 & .000 \\
& $\begin{array}{l}\text { Problem- } \\
\text { solving Ability }\end{array}$ & 5618.667 & 58 & 96.874 & & \\
& Motivation & 2445.367 & 58 & 42.161 & &
\end{tabular}




\begin{tabular}{llll} 
Total & $\begin{array}{l}\text { Problem- } \\
\text { solving Ability }\end{array}$ & 367972.000 & 60 \\
& Motivation & 399887.000 & 60 \\
Corrected & $\begin{array}{l}\text { Problem- } \\
\text { Total }\end{array}$ & 9145.333 & 59 \\
& $\begin{array}{l}\text { solving Ability } \\
\text { Motivation }\end{array}$ & 2492.183 & 59 \\
\hline
\end{tabular}

Based on the MANOVA test analysis on the third hypothesis $\left(\mathrm{H}_{1}: \mu_{\mathrm{i}} \neq \mu_{\mathrm{j}}\right), \mathrm{H}_{0}$ was rejected. There were simultaneous differences in problem-solving abilities and learning motivation between students who were taught using the flashcardbased RBL model and those who were taught using direct instruction. This data is supported by the following test result:

Table 2. Multivariate Test

\begin{tabular}{lllllll}
\hline & Effect & \multicolumn{1}{c}{ Value } & \multicolumn{1}{c}{ F } & Hypothesis df & Error df & Sig. \\
\hline Intercept & Pillai's Trace & 4925,528 & $.994^{\mathrm{a}}$ & 2.000 & 57.000 & .000 \\
& Wilks' Lambda & 4925,528 & $.006^{\mathrm{a}}$ & 2,000 & 57,000 & .000 \\
& Hotelling's Trace & 172826 & $4925.528^{\mathrm{a}}$ & 2.000 & 57.000 & .000 \\
& Roy's Largest Root & 172826 & $4925.528^{\mathrm{A}}$ & 2,000 & 57,000 & .000 \\
Class & Pillai's Trace & .386 & $17894^{\mathrm{a}}$ & 2.000 & 57.000 & .000 \\
& Wilks' Lambda & .614 & $17,894^{\mathrm{a}}$ & 2,000 & 57,000 & .000 \\
& Hotelling's Trace & .628 & $17,894^{\mathrm{a}}$ & 2,000 & 57,000 & .000 \\
& Roy's Largest Root & .628 & $17,894^{\mathrm{a}}$ & 2,000 & 57,000 & .000 \\
\hline
\end{tabular}

Based on the analysis of the scores obtained in the posttest, the summary of the data can be seen in the following figures:

Figure 1. The Percentages of Problem-Solving Indicators

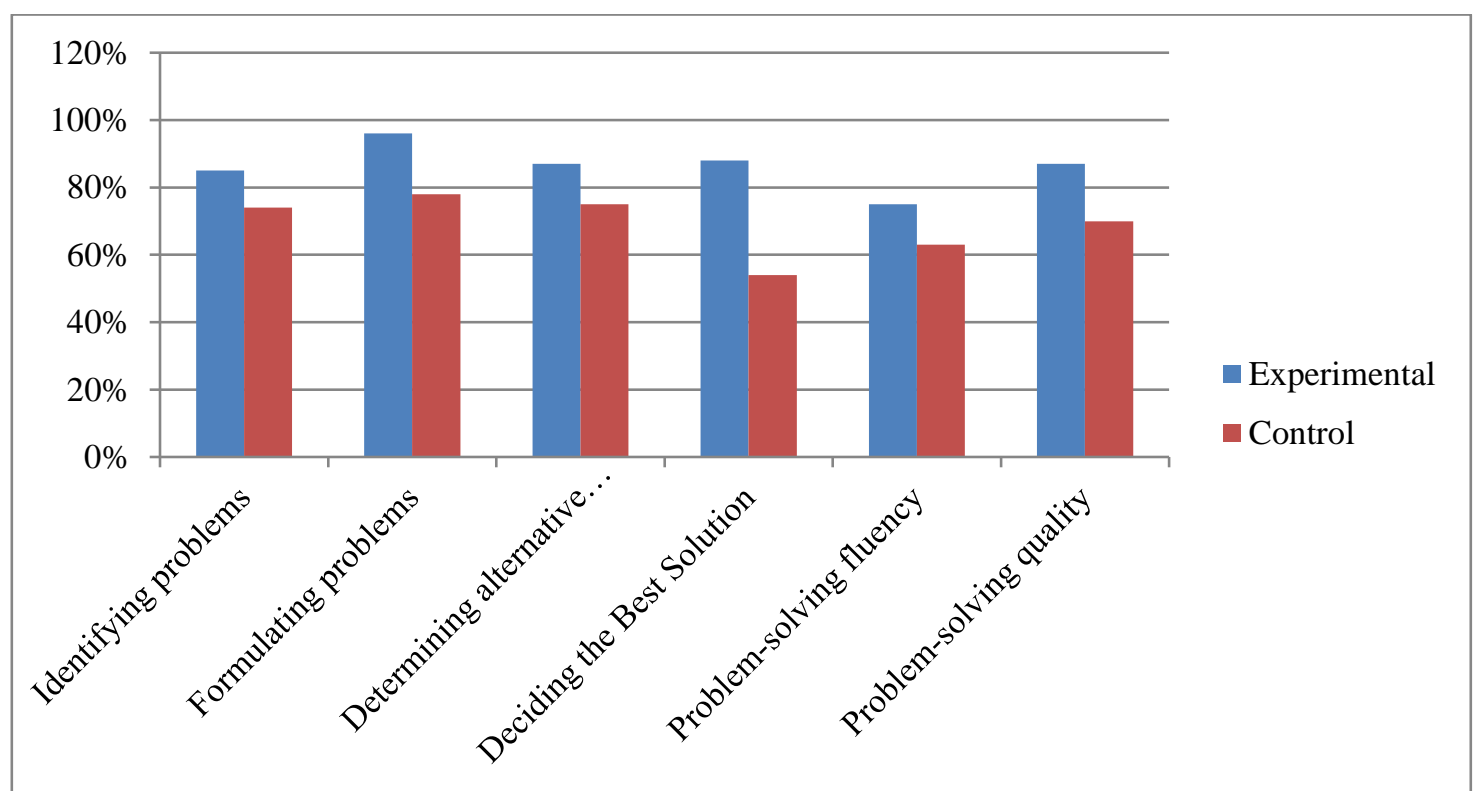


Figure 2. The Percentages of Learning Motivation Indicators

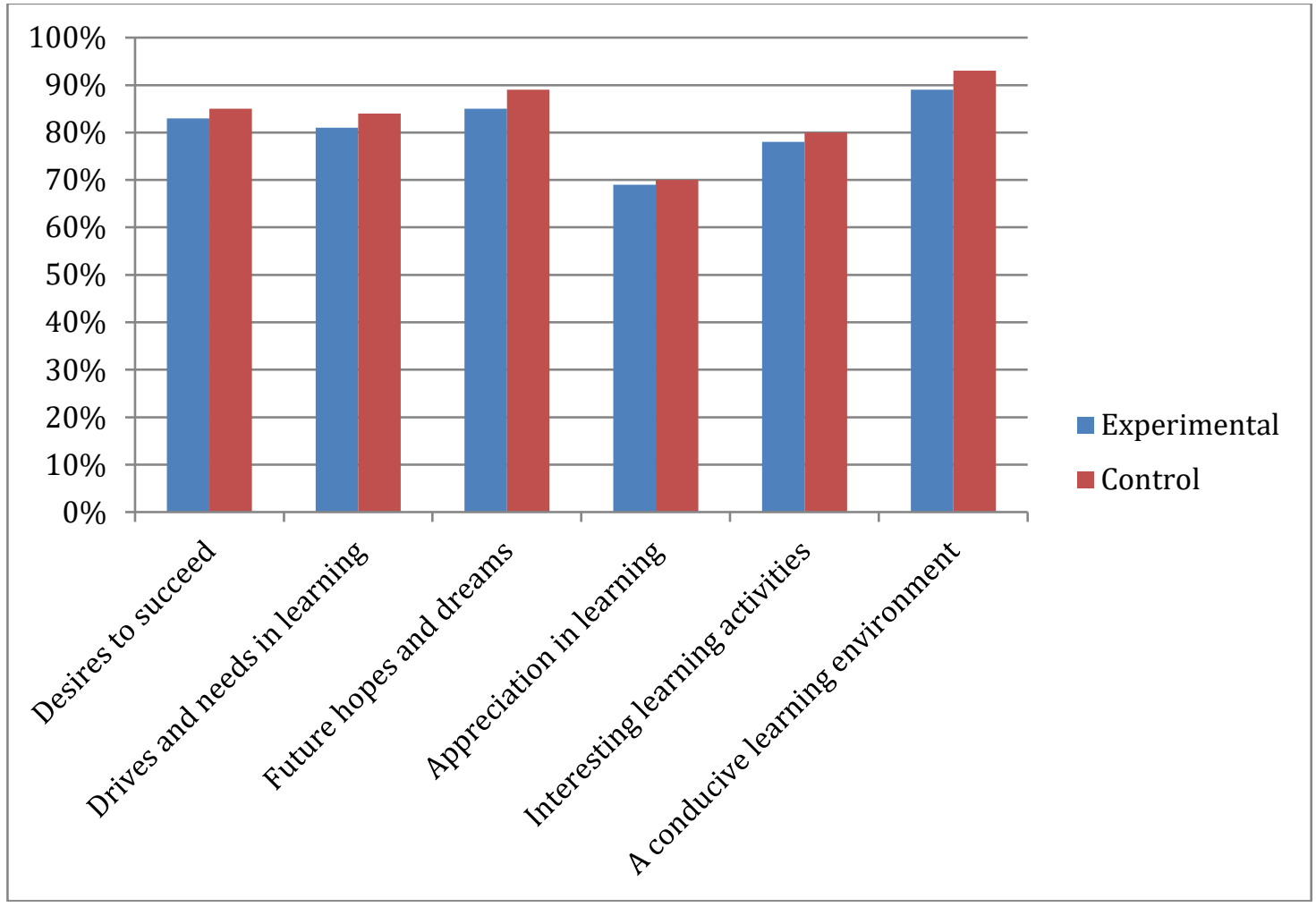

The aspects assessed in the diagram above are based on indicators of learning motivation. The values obtained by the control class were greater than the experimental class. The average percentage obtained by the experimental class was $85 \%$ with an excellent category. It is relevant to the advantage of this model where, in the learning process, students are required to find information and solutions to improve problem-solving abilities. Students are expected to answer by finding existing problems. The average percentage obtained by the experimental class on the first indicator, the desire to succeed, was $83 \%$ and the average percentage of the first indicator obtained by the control class was $85 \%$. In this indicator, students were able to do assignments not because of external encouragement, but from themselves as a desire to succeed.
The average percentage obtained by the experimental class on the indicator of the formulating problem was $96 \%$. One of the syntaxes that support the model is gathering information. In the learning process, students are required to see what possible causes of a problem to occur and group the data obtained. In the drives and needs in learning indicators, the experimental class obtained an average percentage of $81 \%$ and the control class obtained $84 \%$. This was caused by the students' efforts to avoid failure by achieving success in learning.

The average percentage obtained in determining alternative solutions indicator was $89 \%$. Here, students are required to use the information that has been obtained by selecting and sorting the information obtained. The average percentages of the future hopes and aspirations indicator were $85 \%$ and $89 \%$. In this indicator, students had a desire to become class 
champions and get good grades by being diligent in studying and being active in studying so that they could get good results or achievements.

The indicator of deciding the best solution supports the syntax of synthesizing information. The students were able to answer and draw conclusions by selecting and sorting information so that they get the best idea or solution (HASANAH, U. N., Thahir, A., Komaruddin, K., \& Rahmahwaty, R., 2019) The experimental class obtained an average percentage of $88 \%$ and as categorized as excellent. In the appreciation in learning indicators, there was an appreciation for the behavior of students to be more enthusiastic in achieving and getting good grades. This can be seen from the average percentage of $69 \%$ obtained by the experimental class and $70 \%$ obtained by the control class.

The indicators of fluency in solving problems support the syntax of synthesizing information, students can collect data on any facts or all existing problems (Munib, A., 2017). Students did the observations or answered the questions on time with an obtained average percentage of $75 \%$ which is included in the high category. In the interesting learning activities indicator, the experimental class obtained $78 \%$ and the control class obtained $80 \%$. This indicator encouraged students to be able to raise students' focus and seriousness in learning. This is relevant to the resource-based learning model which is to improve students' attitudes and participation in the learning process properly.

The quality of the problemsolving indicator supports the evaluation syntax. Students were able to conclude and explain information by connecting existing problems and finding good solutions. The obtained percentage was $87 \%$ which included in the excellent category. In the conducive learning environment indicator, the experimental class obtained $89 \%$ and the control class obtained 93\%. This indicator was one of the driving forces so that students could be more enthusiastic. With a conducive or comfortable learning environment, students could be more focused on learning.

The high average percentage obtained in the formulating problem indicator was because students can identify possible problems and come out with several problem formulations. The lowest score was found in the indicator of problemsolving fluency. This happened because students were unfamiliar with the learning process, unfamiliar with the learning process that uses time in each learning process, and unfamiliar with combining several factors to create ideas and solutions that are appropriate with the problems.

Based on the data obtained, it was found that the students' learning motivation in the control class was higher than the experimental class. In the control class, the students' learning motivation was high, but there were no supporting resources to channel their drives in learning or achievement because the teacher applied the direct learning model. The students could not actively seek and develop their abilities.

It can be concluded that the students' problem-solving ability and learning motivation was improved through the Resource-based learning model based on flashcard (Rifqiawan, 2017). The class that applied the lecturing and discussion method (the control class) also experienced a 
slight improvement, however the greater improvement was experienced by the experimental class. In conclusion, there was a significant difference in the results of problem-solving abilities and student motivation between the experimental class and the control class.

\section{CONCLUSIONS AND SUGGESTIONS}

Based on the result of research, the Resource-based learning model with flashcard media influenced the problem-solving ability and motivation of the tenth-grade students of SMA YP Unila Bandar Lampung.

It is suggested for further researchers to prepare carefully and understand the Resource-based learning model with flashcard media and prepare sufficient time to carry out the research.

\section{REFERENCES}

Agustiana, N., Supriadi, N., \& Komarudin, K. (2019). Meningkatkan Kemampuan Penalaran Matematis dengan Penerapan Pendekatan Bridging Analogy Ditinjau dari Self-Efficacy. Inovasi Pembangunan: Jurnal Kelitbangan, 7(1), 61-61.

Amri, M. S., \& Abadi, A. M. (2013). Pengaruh PMR dengan TGT terhadap motivasi, sikap, dan kemampuan pemecahan masalah geometri kelas VII SMP. PYTHAGORAS: Jurnal Pendidikan Matematika, 8(1), 55-68.

Balqis, P., Ibrahim, N. U., \& Ibrahim, S. (2014). Kompetensi pedagogik guru dalam meningkatkan motivasi belajar siswa pada SMPN 3 Ingin Jaya Kabupaten Aceh Besar. Jurnal Administrasi Pendidikan: Program Pascasarjana Unsyiah, 2(1).

Cleopatra, M. (2015). Pengaruh gaya hidup dan motivasi belajar terhadap prestasi belajar matematika. Formatif: Jurnal Ilmiah Pendidikan MIPA, 5(2).

Daud, F. (2012). Pengaruh kecerdasan emosional (EQ) dan motivasi belajar terhadap hasil belajar Biologi siswa SMA 3 Negeri Kota Palopo. Jurnal Pendidikan dan Pembelajaran (JPP), 19(2), 243-255.

Emda, A. (2018). Kedudukan motivasi belajar siswa dalam pembelajaran. Lantanida Journal, 5(2), 172-182.

Fanani, M. Z. (2018). Strategi pengembangan soal hots pada kurikulum 2013. Edudeena: Journal of Islamic Religious Education, 2(1).

Hadi, A. (2013). Konsep Analisis SWOT dalam Peningkatan Mutu Lembaga Madrasah. JURNAL ILMIAH DIDAKTIKA: Media Ilmiah Pendidikan dan Pengajaran, 14(1).
HASANAH, U. N., Thahir, A., Komaruddin, K., \& Rahmahwaty, R. (2019). MURDER Learning and Self Efficacy Models: Impact on Mathematical Reflective Thingking Ability. Journal for the Education of Gifted Young Scientists, 7(4), 1123-1135. 
Huda, M. (2015). Peran Pendidikan Islam Terhadap Perubahan Sosial. Edukasia: Jurnal Penelitian Pendidikan Islam, 10(1).

Insyasiska, D., Zubaidah, S., \& Susilo, H. (2017). Pengaruh project based learning terhadap motivasi belajar, kreativitas, kemampuan berpikir kritis, dan kemampuan kognitif siswa pada pembelajaran biologi. Jurnal Pendidikan Biologi, 7(1), 9-21.

Makmur, A., \& Aspia, A. (2015). Efektifitas Penggunaan Metode Base Method dalam Meningkatkan Kreatifitas dan Motivasi Belajar Matematika Siswa SMP Negeri 10 Padangsidempuan. EduTech: Jurnal Ilmu Pendidikan dan Ilmu Sosial, 1(1).

Marwiyah, S. (2012). Konsep pendidikan berbasis kecakapan hidup. Jurnal Falasifa, 3(1).

Munib, A. (207M). Pendekatan Saintifik dalam Meningkatkan Motivasi Belajar Pendidikan Agama Islam. Al-Ulum Jurnal Pemikiran dan Penelitian ke Islaman, 4(2), 243-255.

Nurfitriyanti, M. (2016). Model Pembelajaran Project Based Learning Terhadap Kemampuan Pemecahan Masalah Matematika. Formatif. Jurnal Ilmiah Pendidikan MIPA, 6(2).

Nurseto,T. (2011). Membuat media pembelajaran yang menarik.
Jurnal Ekonomi dan pendidikan, 8(1).

Puspita, L., KOMARUDIN, K., \& Putri, R. A. (2020). Analisis Keterampilan Berpikir Kritis: Dampak Model Pembelajaran SiMaYang dan Concept Map Pada Materi Struktur dan Fungsi Jaringan Pada Tumbuhan. BIOEDUSCIENCE: Jurnal Pendidikan Biologi dan Sains, 4(1), 82-89.

Raharja, H. Y. (2019). Relevansi pancasila era industry 4.0 dan society 5.0 di pendidikan tinggi vokasi. Journal of Digital Education, Communication, And Arts (Deca), 2(1), 11-20.

Rifqiawan, R. A. (2017). Pembuatan Flash Card Digital untuk Pembelajaran $80 \%$ Kosa Kata Al-Qur'an. At-Taqaddum, 8(1), 1-20.

Rifqiawan, R. A. (2017). Pembuatan Flash Card Digital untuk Pembelajaran $80 \%$ Kosa Kata Al-Qur'an. At-Taqaddum, 8(1), 1-20.

Setiawan, I. G. A. N., \& Nyoman, G. A. (2018). Penerapan pengajaran kontekstual berbasis masalah untuk meningkatkan hasil belajar biologi siswa kelas $\mathrm{x} 2$ sma laboratorium singaraja. Jurnal Penelitian dan Pengembangan Pendidikan, 2(1), 42-59.

Sinambela, L. P. (2017). Profesionalisme Dosen Dan Kualitas Pendidikan Tinggi. Jurnal Sosial dan Humaniora, 2(4). 
Suardana, A. A. P. C. P., \& Simarmata, N. (2013). Hubungan antara motivasi belajar dan kecemasan pada siswa kelas VI Sekolah Dasar di Denpasar menjelang Ujian Nasional. Jurnal Psikologi Udayana, 1, 203-212.

Suprihatin, S. (2015). Upaya guru dalam meningkatkan motivasi belajar siswa. Jurnal Pendidikan Ekonomi UM Metro, 3(1), 73-82.

Susanti, M. D. (2015). Pemanfaatan Media Pembelajaran Terhadap Motivasi Belajar Anak TK. Jurnal Pendidikan Anak. 